\title{
SYDÄNKUNTOUTUS JA \\ ERIKOISSAIRAANHOIDON \\ PALVELUJEN KÄYTTÖ
}

\author{
Satunnaistettu tutkimus yli 60-vuotiaiden \\ sepelvaltimotautipotilaiden palvelujen käytöstä \\ sydänkuntoutuksen jälkeen
}

\section{Johdanto}

Sepelvaltimotauti on edelleen merkittävä kansanterveysongelma Suomessa, vaikka siitä aiheutuva kuolleisuus sekä ensikohtausten ilmaantuvuus ovat vähentyneet (Salomaa ym. 2014). Samalla ilmaantuvuuden painopiste on siirtynyt vanhempiin ikäluokkiin, mikä puolestaan asettaa uusia haasteita myös tuloksellisen sydänkuntoutuksen kehittämiselle (Witt ym. 2004; Braverman 2011).

Sydänpotilaiden kuntoutuksen vaikuttavuudesta on tehty useita katsauksia ja meta-analyysejä. Laajassa, 47 tutkimusta sisältävässä Cochrane-katsauksessa todettiin, että liikuntaan perustuva sydänkuntoutus on vaikuttavuudeltaan tehokasta ja vähentää sekä kokonais- että sydänkuolleisuutta. Sydänkuntoutuksen avulla on voitu myös vähentää sairaalakäyntien määrää (Heran ym. 2011; Taylor ym. 2004). Lisäksi psykososiaalisesti painottuneen sydänkuntoutuksen avulla voidaan parantaa kuntoutujien elämänaatua (Heran ym. 2011; Müller-Riemenschneider ym. 2010; Davies ym. 2010; Salminen ym. 2006).

Sydänkuntoutuksen vaikuttavuutta on perinteisesti arvioitu käyttäen vaikuttavuuden osoittimina vaaratekijöiden alenemista, kuolleisuutta, työkyvyn palautumista sekä toi- mintakyvyn ja elämänlaadun kohenemista. Huomattavasti vähemmän on selvitetty sitä, onko sydänkuntoutuksella mahdollisesti vaikutusta myöhempään terveyspalvelujen käyttöön. Voidaan olettaa, että sydänkuntoutuksen myötä saavutettu vaaratekijöiden tason aleneminen ja toimintakyvyn paraneminen heijastuisivat myöhempään terveydenhuollon palvelujen tarpeen vähenemiseen. (Ades 2001; Chen ym. 2015.)

\section{Aikaisempi kotimainen tutkimusnäyttö sydänkuntoutuksen ja terveyspalveluiden käytöstä}

Suomessa kuntoutuksen ja terveyspalveluiden käytön yhteyttä on tiettävästi selvitetty aikaisemmin vain yhdessä tutkimuksessa (Renfors 2005). Tutkimus perustui 206 pohjoiskarjalaisen, iältään 55-75-vuotiaan sydäninfarktipotilaan otokseen. Osallistujat satunnaistettiin kolmeen ryhmään: pitkään laitoskuntoutukseen, lyhyeen laitoskuntoutukseen sekä oman kotipaikkakunnan terveydenhuollon tarjoamien avokuntoutuspalvelujen käyttöön. Osallistujien terveyspalvelujen käyttöä seurattiin kolmessa eri vaiheessa: infarktia edeltäneet kuusi kuukautta, sairastumisesta kuntou- 
tuksen loppuarvioon (14-15 kuukautta) sekä tämän jälkeen kahden vuoden ajalta.

Tutkimuksen päätuloksena todettiin, ettei pitkä, laitosmuotoinen sydänkuntoutus vähentänyt myöhempää palvelujen tarvetta, kun sitä verrattiin lyhyeen laitoskuntoutukseen tai avokuntoutukseen. Palvelujen käyttöä selitti naisten osalta parhaiten masentunut mieliala, miesten osalta puolestaan sairauden vakavuus, jota kuvasivat NYHA-luokka ja infarktien lukumäärä. Kaikkiaan naiset käyttivät palveluja koko seurantajaksolla merkitsevästi miehiä enemmän. (Renfors 2005.)

Vaikka Renforsin (2005) selvityksessä yli puolet käyntimääristä kertyi perusterveydenhuollossa, kustannuksista 84 \% syntyi erikoissairaanhoidossa. Renfors päätteli, että avokuntoutusta kalliimpaan laitoskuntoutukseen ohjaamista ei voida perustella terveydenhuollossa myöhemmin syntyvillä säästöillä. Johtopäätöksen pätevyyttä kuitenkin rajoittaa huomattavasti se, että tutkimuksessa kustannuksia laskettaessa ulkopuolelle jätettiin röntgen- ja laboratoriokäynnit sekä kajoavista toimenpiteistä (esim. sepelvaltimoiden ohitusleikkauksista tai pallolaajennuksista) aiheutuneet kustannukset. Artikkelissa ei myöskään raportoitu käynteihin liittyviä oire- tai syydiagnooseja. Näin ollen ei tiedetä, missä määrin käyntien taustalla on ollut muita kuin valtimotauteihin liittyviä sairauksia, joihin sydänkuntoutuksella ei luonnollisesti voida olettaa olevan vaikutusta. Kyseisessä ikäryhmässä monien muiden sairauksien, kuten esimerkiksi syöpien, ilmaantuvuus on kuitenkin suhteellisen yleistä (Suomen virallinen tilasto 2014).

\section{Sydän 60+ - hankkeen seurantatutkimuksen tavoitteet}

Käsillä oleva tutkimus on toinen osa RAY:n tuella vuonna 2008 käynnistettyä hanketta, jossa selvitettiin 60 vuotta täyttäneiden sepelvaltimotautipotilaiden sydänkuntoutusohjelman toimivuutta ja vaikuttavuutta. Tutkimuksen asetelmana käytettiin satunnaistettua, kontrolloitua hoitokoetta, jossa verrattiin interventio- ja vertailuryhmään satunnaistettuja henkilöitä.
Tutkimuksen ensimmäisen vaiheen puolen vuoden seurantatutkimuksen tulokset osoittivat, että vertailuryhmään nähden tilastollisesti merkitsevästi suotuisampi muutos voitiin todeta interventioryhmäläisillä painoindeksin, LDL-kolesterolin, liikunnan harrastuksen sekä kokonaisriskipisteiden osalta. Vaaratekijöistä vain verenpaineen osalta voitiin vertailuryhmässäkin todeta tilastollisesti merkitsevä aleneminen. Suositusten mukaisia muutoksia ruokavaliossa voitiin todeta molemmissa tutkimusryhmissä, interventioryhmässä 44,3 $\%$ ja vertailuryhmässä 24,3 \%; ero interventioryhmän eduksi oli tilastollisesti merkitsevä (Julkunen ym. 2012, 40).

Elämänlaadun osalta tulokset osoittivat kautta linjan tilastollisesti merkitsevää kohenemista interventioryhmässä, kun taas vertailuryhmässä muutosta ei tapahtunut. Sitä vastoin rasituskokeen avulla arvioidussa fyysisessä suorituskyvyssä tai koettujen rintakipujen määrässä ei kummassakaan tutkimusryhmässä voitu todeta merkitsevää muutosta. Tutkimuksen ensimmäisen vaiheen toteutus, arviointimenetelmät sekä interventio-ohjelma on tarkemmin kuvattu hankkeen pääraportissa (Julkunen ym. 2012).

Tämän, tutkimuksen toisen vaiheen tavoitteena oli selvittää, oliko projektissa kehitetyllä, iäkkäille sydänpotilaille suunnatulla kuntoutusohjelmalla yhteyttä myöhempään erikoissairaanhoidon palvelujen käyttöön sekä tutkia, mitkä perussairauteen, vaaratekijöihin tai toimintakykyyn liittyvät tekijät mahdollisesti selittävät palvelujen käyttöä. Erikoissairaanhoidon palvelujen käyttö valittiin tulosmuuttujaksi, koska siitä aiheutuvat kustannukset ovat erityisen suuria (Purmonen ym. 2016; Renfors 2005) eikä tätä kysymystä ole aikaisemmissa tutkimuksissa erikseen selvitetty.

\section{Menetelmät}

Hankkeen ensimmäinen vaihe toteutettiin vuosina 2008-2011 yhteistyössä Helsingin ja Vantaan kaupunkien terveyskeskusten kanssa. Kuntoutujien rekrytointiin osallistui kaikkiaan 22 terveysasemaa; Helsingistä 14 ja Vantaal- 
ta 8 asemaa. Tutkimuslupaa puoltavat lausunnot saatiin HUS:n eettiseltä toimikunnalta (23.4.2008) sekä Helsingin terveyskeskukselta (14.5.2008) ja Vantaan kaupungilta (2.5.2008).

Tutkimuksen asetelmana käytettiin satunnaistettua, kontrolloitua hoitokoetta, jossa verrattiin kahta ryhmää (kuvio 1). Tutkimuksen asetelma ja menetelmät on kuvattu tarkemmin hankkeen pääraportissa (Julkunen ym. 2012). Potilaat, jotka täyttivät tutkimuksen seulontakriteerit sekä antoivat kirjallisen suostumuksen osallistumisestaan, saivat terveysasemaltaan lähetteen Kuntoutussäätiön Malminkartanon kuntoutuskeskukseen (1.9.2010 - 26.4.2013 Avire 0y).

Kuntoutussäätiössä osallistujat satunnaistettiin interventio- ja vertailuryhmään kahdeksan eri ositteen sisällä siten, että tutkimukseen tulevat jaettiin sukupuolen, iän (alle/yli 70-v.) ja asuinkunnan mukaan. Logistisista syistä vertailuryhmään valittiin osallistujia suhteessa noin $2 / 3$.

Interventioryhmään satunnaistetut osallistuivat iäkkäille sepelvaltimotautipotilaille räätälöidylle avokuntoutuskurssille. Seurantatutkimus toteutettiin kuuden kuukauden kuluttua, jolloin kaikki hankkeeseen osallistuneet saivat erikoislääkärin henkilökohtaisen palautteen omaa terveyttään koskevista tuloksista. Tarvittaessa tulokset raportoitiin potilaan suostumuksella oman terveysaseman hoitavalle lääkärille, joka sai näin erikoislääkärin lausunnon potilaan terveydentilasta. Hankkeeseen osallistumisesta ei koitunut kuluja osallistujille.

Interventio toteutettiin avokuntoutuksena Kuntoutussäätiön Malminkartanon kuntoutuskeskuksessa. Vuosien 2008-2011 aikana toteutettiin 16 kuntoutusryhmää; yhteen ryhmään valittiin 10-12 kuntoutujaa. Ryhmä kokoontui kerran viikossa järjestettyyn kurssipäivään yhteensä yhdeksän kertaa noin kolmen kuukauden aikana sekä yhteen seurantapäivään kolmen kuukauden kuluttua interventiojakson päättymisestä. Intervention toteutti työryhmä, johon kuuluivat sisätautilääkäri, kuntoutuslääkäri, erikoissairaanhoitaja, fysioterapeutti, sosiaalityöntekijä ja psykologi. Heillä kaikilla oli useiden vuosien kokemus sydänkuntoutuksesta ja he vastasivat pääosin tässä toteutetun, iäkkäille sydänpotilaille räätälöidyn kuntoutusintervention sisällön suunnittelusta.

Ohjelmaan kuului ohjattua liikuntaa, rentoutusta ja neuvontaa sydänystävällisestä ravinnosta, sosiaaliturvasta sekä elintapojen vaikutuksesta sepelvaltimotautiin. Niiden kautta pyrittiin tukemaan osallistujien fyysisen suorituskyvyn kohentumista, kognitiivista vireyttä, sosiaalista osallistumista ja psyykkistä hyvinvointia. Ohjelma on yksityiskohtaisemmin kuvattu hankkeen pääraportissa (Julkunen ym. 2012). Interventioryhmään satunnaistetuista ( $\mathrm{n}=192$ ) kieltäytyi 17 (8,9 \%). Ohjelmaan osallistuttiin aktiivisesti, vain neljä henkilöä (2,3 \%) keskeytti ohjelman.

Vertailuryhmään satunnaistetuille suoritettiin vastaavat tutkimukset kuin kuntoutuskurssille osallistuneille, toisin sanoen sairaanhoitajan haastattelu, psyykkisen hyvinvoinnin kyselyt, laboratoriotutkimukset sekä rasituskoe tutkimuksen alussa ja kuuden kuukauden kuluttua. Sekä osallistujille että hoitotahoille postitettiin laboratoriotutkimusten tulokset, rasituskoetulos ja erikoislääkärin lausunto siitä sekä kuntoutuslääkärin palaute veriarvoista ja mahdollisista lisätutkimusehdotuksista. Muutoin vertailuryhmään kuuluvia hoidettiin ja seurattiin silloisten hoitosuositusten ja käytännön mukaisesti.

\section{Osallistujat}

Hankkeeseen osallistujiksi ilmoittautui kaikkiaan 312 yli 59-vuotiasta sepelvaltimotautipotilasta. Heistä 286 (91,7 \%) osallistui lähtötasomittauksiin ja hankkeen ensimmäiseen vaiheeseen. Näistä osallistujista 175 (61,2 \%) oli satunnaistettu interventioryhmään ja 111 $(38,8 \%)$ vertailuryhmään. Kaikkiaan siis 26 henkilöä $(8,3 \%)$ kieltäytyi osallistumista satunnaistamisen mukaiseen ohjelmaan; taustatekijöiden tai toimintakyvyn suhteen he eivät eronneet tilastollisesti merkitsevästi muista osallistujista (Julkunen ym. 2012).

Naisia oli 131 (45,8 \%), iän keskiarvo koko ryhmässä oli 69,5 vuotta ( $\mathrm{kh}=5,77$; vaihteluväli 60-88). Miehiä ja naisia verrattaes- 


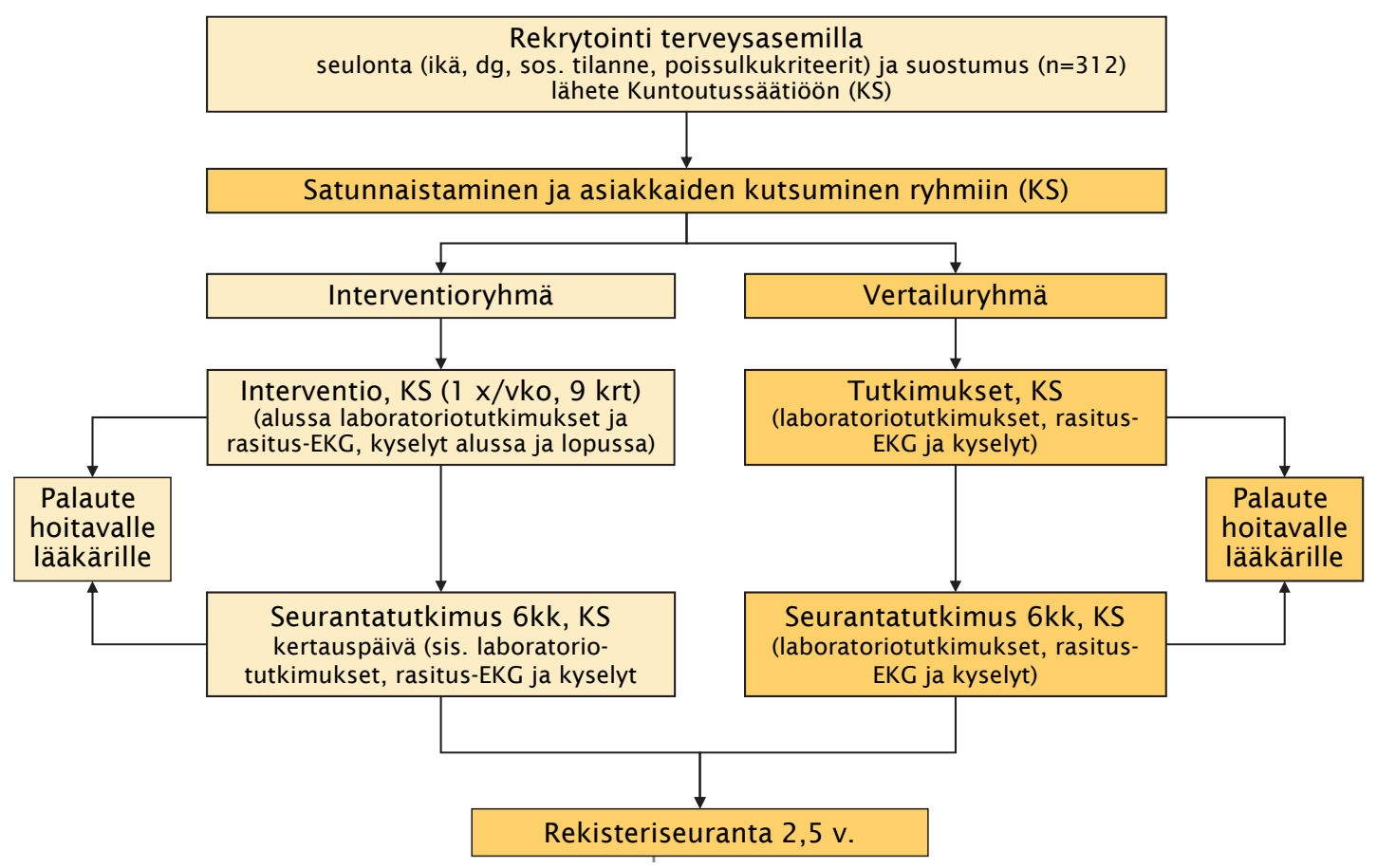

Kuvio 1. Tutkimuksen kulkukaavio (Julkunen ym. 2012).

sa voitiin todeta, että naisista merkitsevästi suurempi osa (62,2 \% vs. 14,2 \% miehistä) oli yksin asuvia. Lisäksi naisten peruskoulutustaso oli jonkin verran korkeampi kuin miehillä (Julkunen ym. 2012). Tutkimusryhmien välillä ei todettu minkään taustamuuttujan suhteen merkitseviä eroja. Osallistujien rekrytointi sekä aineiston tarkemmat sosiodemografiset tiedot on esitetty hankkeen pääraportissa (Julkunen ym. 2012).

\section{Rekisteriseurannan toteutus}

Rekisteritiedot kaikkien tutkimuksen ensimmäiseen vaiheeseen osallistuneiden erikoissairaanhoidon palvelujen käytöstä kerättiin Terveyden ja hyvinvoinnin laitoksen (THL) Hilmo-järjestelmästä vuosilta 2009-2013. Terveydenhuollon perustietolomakkeelta sekä vaativan sydänpotilaan lisätietolomakkeelta poimittiin seuraavia tietoja: hoitoon tulon syy ja tarve, diagnoosit, toimenpiteet, jatkohoito sekä tiedot laitoksiin tehtävistä avokäynneis- tä (ns. benchmarking-tilasto). Seuranta-ajaksi määriteltiin kaksi ja puoli vuotta kunkin osallistujan kuuden kuukauden seurantapäivästä lukien. Lisäksi saatiin Tilastokeskuksesta tutkimukseen osallistuneiden kuolleisuutta koskevat tiedot (kuolinaika ja -syy) vuosilta 2009-2013.

Hilmo-tietokannan tiedoista laskettiin erikoissairaanhoidon toimenpiteiden ja käyntimäärien summa, jossa otettiin huomioon laajasti tulkiten sydän- ja verisuonitautien hoidon vuoksi tapahtuneet käynnit ja toimenpiteet. Diagnoosikategorioista otettiin tällöin huomioon ICD-10 luokituksen mukaiset koodiarvot I00-I99 sekä lisäksi diabetekseen, rytmihäiriöihin tai rintakipuihin viittaavat koodiarvot (E11, E66, R00-01 ja 06-07) ja edelleen toimenpiteinä sepelvaltimoiden ohitusleikkaukset, pallolaajennukset ja sydänkuntoutus. Näin muodostettua käynti- ja toimenpidemääriä kuvaavaa summa-muuttujaa käytettiin erikoissairaanhoidon (esh) palvelujen käyttöä osoittavana tulosmuuttujana. 


\section{Palvelujen käyttöä ennustavat tekijät}

Kuntoutusintervention vaikuttavuuden selvittämiseksi otettiin huomioon palvelujen käyttöä mahdollisesti selittävinä taustatekijöinä ikä, sukupuoli, aikaisempi sairaushistoria, osallistujan taloudellinen tilanne sekä koulutustaso. Aiemman sairaushistorian indikaattoriksi muodostettiin kaksiluokkainen muuttuja siten, että ensimmäiseen luokkaan (1) kuuluvilla oli vain aiemmin diagnosoitu sepelvaltimotauti ja toiseen ryhmään (2) diagnosoitu sydäninfarkti ja/tai suoritettu kajoava toimenpide (sepelvaltimoiden varjoainekuvaus, ohitusleikkaus tai pallolaajennus).

Koulutustasoa kuvattiin kaksiluokkaisella muuttujalla ( 1 = kansakoulu/kansalaiskoulu, 2 = keskikoulu/peruskoulu tai ylioppilastutkinto). Taloudellisen tilanteen osoittimena käytettiin osallistujien itse ilmoittamia henkilökohtaisia kuukausittaisia bruttotuloja.

Lisäksi tarkasteltiin eräiden yksilökohtaisten toimintakykyä ja valtimotautien vaaratekijöitä kuvaavien lähtötasomuuttujien yhteyksiä palvelujen käyttöön. Liikapainon osoittimeksi valittiin tutkimushoitajan mittaama vyötärönympärys. Sen lisäksi muodostettiin painoindeksiin perustuva 3-luokkainen muuttuja, jossa yli 60-vuotiaita koskevien Käypä hoito -suositusten mukaisen painoindeksialueen $(24-29 \mathrm{~kg} / \mathrm{m} 2$; arvo = 0) alapuolelle jääneet saivat arvon 1 ja sen ylittäneet arvon 2 (Käypä hoito -suositus 2011). Vähäisen liikunta-aktiivisuuden osoittimeksi muodostettiin alkukyselyn vastauksen perusteella kaksiluokkainen muuttuja, jossa 0-luokkaan kuuluvat ilmoittivat harrastavansa liikuntaa, joka sai aikaan hengästymistä ja hikoilua, vähintään kolme kertaa viikossa ja 1-luokkaan ne, jotka harrastivat tällaista liikuntaa harvemmin.

Vaaratekijöiden kokonaistason osoittimina käytettiin tutkimuksessa sovellettua vaaratekijöiden summa-indeksiä, jossa mukana olivat painoindeksi, tupakointi, liikunta-aktiivisuus, systolinen ja diastolinen verenpaine sekä kokonaiskolesteroli. Indeksin muodostaminen on tarkemmin kuvattu hankkeen pääraportissa (Julkunen ym. 2012).

Toimintakyvyn osoittimina käytettiin kliinisen rasituskokeen neljän viimeisen rasitus- minuutin työn keskiarvoa (Wmax4). Lisäksi tarkasteltiin RAND-36 sairauteen liittyvän elämänlaatu-kyselyn (Aalto ym. 1999) tuloksista muodostettua fyysistä (QLfys) ja psyykkistä (QLpsy) toimintakykyä kuvaavia summamuuttujia (tarkemmin, Julkunen ym. 2012; Julkunen \&t Ahlström 2006). Masennusoireita arvioitiin Raitasalon (2007) modifioimalla Beck'in depressio-asteikolla.

\section{Tilastolliset menetelmät}

Tuloksia tarkasteltiin analysoimalla prosenttijakaumia, keskiarvoja sekä keskihajontoja. Alaryhmien välisiä eroja testattiin luokiteltujen muuttujien osalta khi2-testillä ja MannWhitney'n U-testillä sekä jatkuvien muuttujien osalta riippumattomien otosten t-testillä ja varianssianalyysillä. Muuttujien välisiä yhteyksiä tarkasteltiin Spearmanin rho-kertoimella. Palvelujen käyttömääriä ennustavia yksilökohtaisia tekijöitä analysoitiin korrelaatioiden ja multinomiaalisen logistisen regression avulla. Tutkimusaineiston tiedot analysoitiin IBM SPSS 22.0 -ohjelmistolla, logistisen regressiomallin analyysit tehtiin STATA 12 -ohjelmistolla.

\section{Tulokset}

\section{Sydänkuntoutuksen yhteys kuolleisuuteen}

Tutkimukseen osallistujista oli vuoden 2013 loppuun mennessä kuollut yhteensä 16 henkilöä (5,1 \%). Seuranta-ajaksi muodostui tällöin kuolleisuuden osalta kuntoutuksen alkamisesta laskien 38-64 kk. Kuolemista 11 voitiin luokitella sydänperäisiksi ja viisi muista syistä johtuviksi, näistä neljä oli syöpäkuolemia.

Taustatekijöiden osalta voitiin todeta, että kuolleet olivat keskimäärin 4,5 vuotta vanhempia kuin elossa olevat, ero oli tilastollisesti merkitsevä ( $p=0.003)$. Miesten kuolleisuus oli suuntaa antavasti korkeampi kuin naisten $(7,1$ $\%$ vs. $2,8 \%$ vastaavasti, $\mathrm{p}=0.086$ ); ikävakioituna ero oli tilastollisesti lähes merkitsevä $(\mathrm{F}(1)=4,77, \mathrm{p}=0.030)$. Sitä vastoin tulo- ja koulutustasolla, yksin elämisellä tai asuinkunnalla ei ollut yhteyttä kuolevuuteen. 
Kun edelleen tarkasteltiin aikaisemmin diagnosoituja sydäninfarkteja tai aiemmin suoritettuja kajoavia toimenpiteitä (sepelvaltimoiden ohitusleikkaukset, varjoainekuvaukset tai pallolaajennukset), ei näilläkään voitu todeta tilastollisesti merkitsevää yhteyttä kuolleisuuteen tässä aineistossa (kaikki p-arvot $>0.200$ ).

Kuolleista 12 oli satunnaistettu interventioryhmään ja neljä verrokkeihin. Ryhmien välinen ero (6,3 \% vs. 3,3 \%) ei ollut tilastollisesti merkitsevä ( $p=0.256)$. Ja vaikka otettiin huomioon vain sydänperäiset kuolemat, ryhmien välinen ero oli edelleen ei-merkitsevä (4,3 \% vs. $2,5 \%$; p > 0.4). Myöskään iän kontrolloiminen ei muuttanut tulosta. Pienten kuolleisuuslukujen vuoksi tarkemmat tilastolliset analyysit tältä osin eivät olleet perusteltuja.

\section{Erikoissairaanhoidon palvelujen käyttö}

Palvelujen käytön arvioimiseksi muodostettiin siis summamuuttuja, johon laskettiin laajasti tulkiten sydän- ja verenkiertosairauksista johtuvat käynnit tai toimenpiteet, jotka olivat toteutuneet kahden ja puolen vuoden aikana kunkin osallistujan kuuden kuukauden seurantapäivästä laskien. Näistä analyyseista jätettiin pois kaksi tapausta, jotka olivat kuolleet jo ennen rekisteriseurannan alkua.

Tulokset osoittivat, että tässä aineistossa $(\mathrm{N}=310)$ oli 139 (44,8 \%) henkilöä, joilla ei ollut lainkaan rekisteriin merkittyjä erikoissairaanhoidon käyntejä tai toimenpiteitä seurantajakson aikana. Siis lähes puolet tutkimukseen osallistuneista ei ollut käyttänyt interventiota seuranneiden 2,5 vuoden aikana sydänsairauksiin liittyviä erikoissairaanhoidon palveluja. Interventioryhmässä heitä oli 87 /190 (45,8 \%) ja verrokeissa 52/120 (43,3 $\%$; tutkimusryhmien välinen ero ei ollut tilastollisesti merkitsevä (khi2 $=0.179, \mathrm{df}=1$, $\mathrm{p}=0.670$ ).

Seuraavaksi verrattiin taustatekijöiden suhteen henkilöitä, jotka olivat käyttäneet esh-palveluita niihin, jotka eivät olleet käyttäneet esh-palveluita. Iän ja tulotason yhteyttä palvelujen käyttöön analysoitiin 2-suuntaisel- la varianssianalyysillä, jossa ryhmittelijöinä olivat luokiteltu palvelujen käyttö/ei-käyttö ja tutkimusryhmä. Tulokset osoittivat, että eshpalveluja käyttäneet olivat keskimäärin noin kaksi vuotta vanhempia (68,5 vs. 70,8 vuotta), ero oli tilastollisesti merkitsevä $(\mathrm{F}=9,78, \mathrm{df}=$ $1, \mathrm{p}=0.002$ ). Ero oli molemmissa tutkimusryhmissä samansuuntainen eikä sukupuolen kontrolloiminen muuttanut tulosta. Tulotasolla puolestaan ei ollut merkitsevää yhteyttä tai yhdysvaikutusta palvelujen käyttöön (p-arvot $>0.300$ ).

Luokiteltuina muuttujina tarkasteltiin vielä sukupuolen, koulutustason, sairaushistorian ja yksin asumisen mahdollisia eroja palveluja käyttäneiden ja ei käyttäneiden välillä. Suorat yhteydet olivat kaikilta osin tilastollisesti eimerkitseviä (kaikki p-arvot > 0.200). Yhteenvetona taustatekijöistä voidaan todeta, että vain ikä erotteli merkitsevästi erikoissairaanhoidon palveluja käyttäneet ei-käyttäjistä.

\section{Palvelujen käyttömäärää selittävät yksilölliset tekijät}

Kuten palveluja käyttämättömien suuren osuuden (44,8 \%) perusteella voitiin odottaa, palvelujen käyttöä kuvaavan summamuuttujan jakauma osoittautui huomattavasti normaalista poikkeavaksi (vinous $=7,56$ ) ja sen vaihteluväliksi 0-76. Verrokkien joukossa todettiin yksi huomattavasti muista poikkeava tapaus (käyntejä 76), joka päätettiin poistaa jatkoanalyyseista, jolloin vaihteluväliksi muodostui 0-26. Tämän jakauman keskiarvo oli $2,34(\mathrm{kh}=4,00)$, mediaani $=1.00$ sekä vinous 2,86 . Palveluja käyttäneiden käyntimäärät vaihtelivat tyypillisesti yhdestä viiteen 2,5 vuoden seurantajaksolla (41,7 \%), ja vain 13,3 \%:n osalta käyntejä tai toimenpiteitä oli tätä enemmän. Kaikista käynneistä kajoavien toimenpiteiden määrä oli yhteensä 11 (1,6 \%), niistä kolme ohitusleikkauksia. Kuntoutusryhmään osallistuneiden ja verrokkien joukossa kajoavien toimenpiteiden tapausmäärät olivat samaa tasoa (3,7 \% vs 3,4 \%, vastaavasti).

Tutkimusryhmien käyntimäärien jakaumia verrattiin Mann-Whitney'n U-testillä, joka osoitti, ettei ryhmien välillä ollut merkitse- 
Taulukko 1. Yksilökohtaisten tekijöiden korrelaatiot (Spearman's Rho) seurantajakson aikana kirjattujen sydänsairauksiin liittyvien erikoissairaanhoidon käyntien ja toimenpiteiden määrään miehillä ja naisilla.

\begin{tabular}{|c|c|c|}
\hline & $\begin{array}{l}\text { MIEHET } \\
n=154\end{array}$ & $\begin{array}{l}\text { NAISET } \\
n=129\end{array}$ \\
\hline Tutkimusryhmä/verrokki & $-0,02$ & $-0,04$ \\
\hline Ikä & $0,32 * * *$ & 0,15 \\
\hline Elää yksin & $-0,21 * *$ & $-0,08$ \\
\hline Sairaushistoria $^{1}$ & 0,11 & $-0,04$ \\
\hline Riskipistesumma² & 0,04 & $0,20 *$ \\
\hline BMI/alle suosituksen ${ }^{3}$ & 0,07 & 0,05 \\
\hline BMI/yli suosituksen ${ }^{3}$ & 0,02 & 0,17 \\
\hline Vyötärönympärys & 0,00 & $0,21 *$ \\
\hline Vähäinen liikunta ${ }^{4}$ & 0,03 & $0,31 * * *$ \\
\hline Rasituskoe (W4min) ${ }^{5}$ & $-0,42 * * *$ & $-0,32 * * *$ \\
\hline Elämänlaatu/fyysinen toimintakyky ${ }^{6}$ & $-0,27 * * *$ & $-0,27^{* *}$ \\
\hline Elämänlaatu/psyykkinen toimintakyky $\underline{\underline{6}}$ & $-0,09$ & $-0,13$ \\
\hline Depressiivisyys $^{7}$ & 0,12 & 0,05 \\
\hline
\end{tabular}

${ }^{1}$ Sairaushistoria ennen sepelvaltimotautia

2Painoindeksi, tupakointi, liikunta-aktiivisuus, verenpaine ja kolesteroli

${ }^{3} \mathrm{BMI} /$ alle suosituksen; miehet $\mathrm{n}=115$, naiset $\mathrm{n}=89, \mathrm{BMI} / \mathrm{yli}$ suosituksen; miehet $\mathrm{n}=122$, naiset $\mathrm{n}=100$

$* p<.05 ; * * p<.01 ; * * * p<.001$

${ }^{4}$ Liikuntaa $<3$ kertaa/vko

${ }^{5}$ Rasituskoe (4 rasitusmin. työn ka, W4min) miehet $n=146$; naiset $n=122$, puuttuvista tiedoista johtuen.

${ }^{6}$ Arvioituna RAND-asteikolla

${ }^{7}$ Arvioituna RBDI-depressioasteikolla

vää eroa ( $\mathrm{p}=0.921)$. Vastaavasti ei myöskään miesten ja naisten välillä ollut merkitsevää eroa palvelujen käyttömäärissä ( $\mathrm{p}=0.822)$; iän kontrolloiminen ei muuttanut tulosta. Myöskään aikaisemman sairaushistorian tai koulutustason yhteys palvelujen käyttömäärään ei ollut tilastollisesti merkitseviä (p-arvot 0.611 ja 0.283 , vastaavasti).

Sen sijaan siviilisäädyn tarkastelu osoitti, että yksin elävien ja perheellisten palvelujen käyttömäärät erosivat tilastollisesti merkitsevästi $(p=0.029)$. Tämän tuloksen analysointia tarkennettiin 2-suuntaisella ANOVAlla, jossa ryhmittelijöinä olivat kaksiluokkainen siviilisääty ja sukupuoli sekä kovariaatteina ikä ja tutkimusryhmä. Näin tarkasteltuna sekä yksin elämisellä että sukupuolella oli merkitsevä yhteys palvelujen käyttöön ( $p$-arvot 0.013 ja 0.032 vastaavasti), ja niiden yhdysvaikutus oli myös merkitsevä ( $p=0.029)$. Korkeimmat käyntimäärät kasautuivat yksin elävien miesten osalle ( $\mathrm{ka}=5,09, \mathrm{kh}=6,1)$, kun ne muiden kohdalla vaihtelivat välillä 1,94 (perheelliset miehet) ja 2,46 (yksin elävät naiset).

Seuraavaksi tarkasteltiin vielä eräiden vaaratekijöiden sekä toimintakykyä kuvaavien muuttujien korrelatiivisia yhteyksiä eshpalvelujen käyttöön erikseen miehillä ja naisilla; tulokset on esitetty taulukossa 1 .

Taulukosta käy ilmi, että runsaampaan esh-palvelujen käyttöön korreloivat sekä miehillä että naisilla selvimmin huono fyysinen toiminta- ja suorituskyky. Niiden lisäksi miehillä vain ikä ja yksin asuminen olivat tilastollisesti merkitsevästi yhteydessä käyntimäärään. Naisilla toimintakyvyn osoittimien lisäksi myös vaaratekijöistä vähäinen liikunta sekä vyötärönympärys korreloivat esh-palve- 
Taulukko 2. Taustamuuttujien, valtimotaudin vaaratekijöiden ja elämänlaadun yhteys erikoissairaanhoidonpalveluiden määrään (mallissa 1 esh-palveluiden määrä $=1-2$; mallissa 2 esh-palveluiden määrä $>3$ ) miehillä ja naisilla multinomiaalisen logistisen regressioanalyysin mukaan.

\begin{tabular}{|c|c|c|c|c|c|c|c|c|}
\hline & \multicolumn{4}{|c|}{$\begin{array}{l}\text { MIEHET } \\
n=146\end{array}$} & \multicolumn{4}{|c|}{$\begin{array}{l}\text { NAISET } \\
\mathrm{n}=122\end{array}$} \\
\hline & \multicolumn{2}{|c|}{ ESH-käyntejä 1-2 } & \multicolumn{2}{|c|}{ ESH-käyntejä > 3} & \multicolumn{2}{|c|}{ ESH-käyntejä 1-2 } & \multicolumn{2}{|c|}{ ESH-käyntejä > 3} \\
\hline & OR & $95 \% \mathrm{Cl}$ & OR & $95 \% \mathrm{Cl}$ & OR & $95 \% \mathrm{Cl}$ & OR & $95 \% \mathrm{Cl}$ \\
\hline Tutkimusryhmä/verrokki & 0,60 & $-0,25-1,45$ & $-0,33$ & $-1,34-0,68$ & $-0,47$ & $-1,46-0,52$ & $-0,42$ & $-1,46-0,63$ \\
\hline lkä & 0,04 & $-0,05-0,13$ & 0,04 & $-0,06-0,14$ & 0,03 & $-0,08-0,15$ & $-0,03$ & $-0,14-0,09$ \\
\hline Elää yksin & $-0,60$ & $-1,99-0,80$ & $-0,28$ & $-1,65-1,08$ & $-0,07$ & $-1,06-0,91$ & 0,21 & $-0,85-1,28$ \\
\hline BMI/alle suosituksen ${ }^{1}$ & 0,14 & $-1,21-1,49$ & $-0,11$ & $-1,59-1,36$ & 0,66 & $-0,82-2,13$ & 1,52 & $-0,09-3,13$ \\
\hline BMI/yli suosituksen ${ }^{1}$ & 0,43 & $-0,93-1,80$ & $-0,05$ & $-1,63-1,53$ & 0,25 & $-1,12-1,63$ & 0,09 & $-1,40-1,59$ \\
\hline Vyötärönympärys & 0,01 & $-0,06-0,08$ & 0,00 & $-0,08-0,08$ & 0,03 & $-0,04-0,10$ & 0,06 & $-0,02-0,13$ \\
\hline Vähäinen liikunta ${ }^{2}$ & $-0,85$ & $-1,84-0,15$ & $-0,78$ & $-1,84-0,28$ & 0,80 & $-0,26-1,86$ & $1,20^{*}$ & $0,06-2,33$ \\
\hline Rasituskoe (W4min) ${ }^{3}$ & $-0,02^{*}$ & $-0,04-0,02$ & $-0,04^{* *}$ & $-0,06-0,01$ & 0,01 & $-0,02-0,04$ & $-0,05 * *$ & $-0,09-0,01$ \\
\hline Elämänlaatu/fyysinen ${ }^{4}$ & 0,00 & $-0,03-0,02$ & $-0,03^{*}$ & $-0,05-0,00$ & $-0,02$ & $-0,06-0,01$ & $-0,01$ & $-0,04-0,02$ \\
\hline
\end{tabular}

HUOM! Malli 1 = esh-käyntejä 1-2; Malli 2 = ehs-käyntejä > 3

$\mathrm{OR}=$ ristitulosuhde, $95 \% \mathrm{Cl}=95 \%$ luottamusväli

$* \mathrm{p}<.05 ; * * \mathrm{p}<.01 ; * * * \mathrm{p}<.001$

${ }^{1} \mathrm{BMI} /$ alle suosituksen; miehet $\mathrm{n}=115$, naiset $\mathrm{n}=89$, BMI/yli suosituksen; miehet $\mathrm{n}=122$, naiset $\mathrm{n}=100$

$* \mathrm{p}<.05 ; * * \mathrm{p}<.01 ; * * * \mathrm{p}<.001$

${ }^{2}$ Liikuntaa $<3$ kertaa/vko

${ }^{3}$ Rasituskoe (4 rasitusmin. työn ka, W4min) miehet $n=146$; naiset $n=122$, puuttuvista tiedoista johtuen

${ }^{4}$ Arvioituna RAND-asteikolla

lujen käyttöön, ja myös tutkimuksessa sovellettu riskipistesumma oli yhteydessä suureen käyntimäärään. Merkille pantavaa on myös se, että aiemman sairaushistorian vakavuus ei ollut yhteydessä esh-palvelujen tarpeeseen.

Lopuksi tarkasteltiin esh-käyntimääriä vahvimmin ennustavien tekijöiden yhteisvaikutusta multinomiaalisen logistisen regression avulla erikseen miehillä ja naisilla. Tätä varten käyntimäärät luokiteltiin kolmeen luokkaan: 0 = ei käyntejä, 1 = 1-2 käyntiä, 3 = 3-26 käyntiä. Tulokset on esitetty taulukossa 2 .

Näin analysoituna osoittautui, että eshpalvelujen käyttöä vahvimmin selittäväksi tekijäksi sekä miehillä että naisilla kiteytyi rasituskokeella arvioitu fyysinen suorituskyky. Sen lisäksi lähes merkitsevinä tekijöinä olivat miehillä heidän itseraportoimansa fyysinen elämänlaatu ja toimintakyky sekä naisilla vähäinen liikunta (ks. taulukko 2).

\section{Pohdinta}

Erikoissairaanhoidon osuus on tuoreen selvityksen mukaan noin kolmannes terveydenhuollon kokonaismenoista, ja verenkiertoelinten sairauksien osuus näistä kustannuksista on kolmanneksi suurin (Purmonen ym. 2016). Sydänkuntoutuksen mahdollista vaikutusta näiden palvelujen käyttöön ei kuitenkaan ole aiemmin erikseen selvitetty. Tiedossamme on vain yksi kotimainen tutkimus, jossa tarkasteltiin laitosmuotoisen ja avokuntoutuksen yhteyksiä myöhempään terveydenhuollon palvelujen käyttöön yleensä. Siinä esitetyt tulokset viittasivat siihen, ettei laitoskuntoutus vähentänyt myöhempää terveyspalvelujen käyttöä tai kustannuksia verrattuna avokuntoutukseen (Renfors 2005). Lisäksi tuloksien luotettavuutta rajoittavat eräät johdannossa esiin nostetut seikat, kuten muiden kuin valtimotautien osuuden jättäminen huomiotta. 
Käsillä olevan tutkimuksen tulosten luotettavuutta puolestaan tukevat satunnaistettu tutkimusasetelma, sosiodemografisten taustatekijöiden monipuolinen kontrollointi sekä erikoissairaanhoidon palvelujen käytön rajaaminen nimenomaan sydän- ja verisuonisairauksiin liittyviin käynteihin ja toimenpiteisiin. Johtopäätöksien pitävyyttä rajoittavat toisaalta suhteellisen lyhyt seuranta-aika suhteessa otoskokoon.

Tämän tutkimuksen ensimmäisessä vaiheessa saatiin interventioryhmässä lähes kaikkien keskeisten vaaratekijöiden (esim. veren kolesteroliarvot ja ylipaino) tasoja laskemaan tilastollisesti merkitsevästi enemmän kuin verrokeilla (Julkunen ym. 2012). Tällä perusteella sekä eräiden aiempien tutkimusten perusteella saattoi olettaa, että interventioryhmässä sairauden ennuste olisi suotuisampi ja vastaavasti erikoissairaanhoidon tarve vähäisempi kuin verrokeilla.

\section{Päätulokset}

Tässä saadut tulokset viittaavat kuitenkin siihen, että tutkimuksessa sovelletulla kuntoutusinterventiolla ei ollut merkitsevää yhteyttä interventiota seuranneiden kahden ja puolen vuoden aikana rekisteröityjen, sydän- ja verisuonisairauksiin liittyvien erikoissairaanhoidon palvelujen käyttöön. Kaikkiaan tämä tulos on samansuuntainen kuin Renforsin (2005) lähes vastaavan ikäisiin sydänpotilaisiin perustuneen selvityksen päätulos.

Vastemuuttujana erikoissairaanhoidon palvelujen käyttö on kustannustensa vuoksi tärkeä mutta myös ankara sydänkuntoutuksen tuloksellisuuden kriteeri. Saattaa olla, että kahden ja puolen vuoden seuranta-aika tässä käytettävissä olleen otoksen kokoon nähden on liian lyhyt vaaratekijöiden alentamiseen fokusoidun kuntoutusintervention kuntoutuksen vaikutusten osoittamiseen. Toisaalta on mahdollista, että saavutetut suotuisat elintapamuutokset ovat hiipuneet puolen vuoden seurannan jälkeen. Toinen mahdollinen selitys voisi olla, että interventiolla saavutetut suotuisat muutokset vaaratekijöissä - vaikka olivatkin tilastollisesti merkitseviä - eivät olleet niin suuria, että ne heijastuisivat merkitsevästi erikoissairaanhoidon palvelujen tarpeeseen.

Lisäksi kiinnittää huomiota niiden henkilöiden odottamattoman suuri määrä, joilla ei rekisteritietojen mukaan ollut lainkaan sydänsairauksiin liittyviä erikoissairaanhoidon käyntejä tai toimenpiteitä. Myönteinen tulkinta tuloksista olisi se, että iäkkäätkin sepelvaltimotautipotilaat selviävät varsin hyvin nykykäytännön mukaisen hoidon ja seurannan turvin. Keskimäärin tässä aineistossa esh-käyntejä kertyi 2,34 osallistujaa kohti, mikä merkitsee noin yhtä esh-käyntiä vuodessa. Myönteistä tulkintaa tukisi myös kajoavien toimenpiteiden vähäinen määrä kahden ja puolen vuoden seurannan aikana. Jatkotutkimuksissa olisi ilmeisesti tarpeen ottaa huomioon myös perusterveydenhuollon palvelujen käyttö, kun pyritään selvittämään sydänkuntoutuksen vaikutuksia kokonaisuudessaan.

Palvelujen käyttäjiä ja ei-käyttäjiä verrattaessa ei voitu todeta merkitsevää eroa sukupuolen, tulo- tai koulutustason suhteen. Sen sijaan ilmeni, että poikkeavan suuria käyntimääriä kasautui yksin eläville miehille. Tätä ryhmää on eräissä aiemmissakin selvityksissä päädytty pitämään valtimoterveyden kannalta riskiryhmänä (Case ym. 1992; 0'Shea ym. 2002; Julkunen ym. 2012). Esimerkiksi laajaan kanadalaiseen aineistoon perustuvassa tutkimuksessa (Schmaltz ym. 2007) todettiin sydäninfarktin sairastaneiden, yksin elävien miesten riski kuolla merkitsevästi suuremmaksi kuin yksin elävien naisten tai perheellisten henkilöiden. Ei kuitenkaan tiedetä, mitkä välittävät tekijät selittäisivät tämän useassa tutkimuksessa todetun yhteyden. Kysymys voi olla epäsuotuisista elintavoista ja/tai sosiaalisen tuen vähäisyydestä ja sitä kautta vaaratekijöiden kasautumisesta.

Tässä aineistossa kuitenkin miesten yksin elämisen selitysvoima hiipui ei-merkitseväksi, kun sitä analysoitiin yhdessä fyysisen suorituskyvyn tulosten kanssa. Suoritetussa post hoc -analyysissä kävi ilmi, että yksin elävien ja perheellisten miesten rasituskokeen tulokset erosivat erittäin merkitsevästi ( $\mathrm{t}(144)$ $=4,210, \mathrm{p}<0.001)$. Naisten osalta vastaavaa eroa ei voitu todeta $(p=0.987)$. 
Tämän hankkeen pääraportissa todettiin myös, että yksin elävät sekä miehet että naiset harrastivat vähemmän liikuntaa kuin perheelliset, sen sijaan perinteisten sepelvaltimotaudin vaaratekijöiden suhteen ei voitu todeta merkitsevä eroja (Julkunen ym. 2012, 35). Näyttää siis siltä, että huono fyysinen suorituskyky ainakin osin selittäisi yksin elävien miesten muita runsaamman esh-palvelujen käytön. Asian tarkempi selvittäminen on kuitenkin jatkotutkimuksissa tarpeen, jotta valtimotautien ennaltaehkäisy ja kuntoutustoimenpiteet voitaisiin suunnata tuloksellisesti.

Edelleen palvelujen käyttömäärää selittävien yksilökohtaisten tekijöiden tarkastelu osoitti odotetusti, että vanhemmat potilaat käyttivät useammin erikoissairaanhoidon palveluja kuin nuoremmat. Kuten yksin elämisen, myös iän selitysvoima kuitenkin laski ei-merkitseväksi, kun ennustemallissa oli mukana fyysisen toimintakyvyn osoittimia.

Kaikkiaan voimakkaimmin käyntimääriä selittäväksi tekijäryhmäksi osoittautuivat fyysistä suoritus- ja toimintakykyä eri aspekteista kuvaavat muuttujat, erityisesti rasituskokeen tulos, sekä miehillä myös oma arvio terveyteen liittyvästä fyysisestä elämänlaadusta.

Vaikka keskeiset tulokset olivat sekä miehillä että naisilla varsin samansuuntaiset, korrelaatioiden tasolla voitiin havaita joitain eroja. Naisten joukossa liikunta-aktiivisuus näytti olevan jossain määrin tärkeämpi vähäiseen käyntimäärään liittyvä tekijä kuin miehillä. Lihavuuden ja muiden vaaratekijöiden merkitys näytti kuitenkin selittyvän fyysisen suorituskyvyn kautta. Renforsin (2005) tuloksista poiketen masentuneisuudella ei tässä tutkimuksessa etenkään naisten osalta ollut yhteyttä myöhempään esh-palvelujen käyttöön. Tämä selittynee sillä, että Renfors ei tarkastellut erikseen perusterveydenhuollon ja erikoissairaanhoidon palvelujen käyttöä tältä kannalta. Näiden palvelusektoreiden sekä sukupuoleen mahdollisesti liittyvien erojen merkitystä on syytä selvittää tarkemmin myöhemmissä tutkimuksissa (Keeley \&t Driscoll 2010).

\section{Sydänkuntoutuksen kehittäminen}

Yhtenä selityksenä siihen, että kuntoutusinterventiolla ei voitu todeta merkitsevää yhteyttä myöhempään erikoissairaanhoidon palvelujen käyttöön, voisi tällä perusteella olla intervention tuloksettomuus fyysisen suorituskyvyn parantajana. Projektin aiemmassa raportissahan jouduttiin toteamaan, että rasituskokeella arvioidussa fyysisessä suorituskyvyssä ei kummankaan tutkimusryhmän osalta tapahtunut juuri lainkaan muutosta. Tämän lisäksi erityisesti verrokkiryhmän miesten suorituskyky oli sekä tutkimuksen alussa että kuuden kuukauden seurannassa hivenen interventioryhmän miesten suorituskykyä parempi. (Julkunen ym. 2012.)

Aiemmassa raportissa pohdittiin myös syitä vähäisiin tuloksiin fyysisen suorituskyvyn osalta ja arveltiin, että interventioryhmien suuri koko (8-12 henkeä) sekä ryhmien suuri heterogeenisyys rajoittivat merkittävästi liikuntaohjelman rasittavuuden tasoa ja monipuolisuutta. Iäkkäiden sydänpotilaiden tehokas liikunnallinen kuntoutus on parhaiten toteutettavissa selvästi pienemmissä ryhmissä, joissa osallistujien yksilölliset ominaisuudet voidaan paremmin huomioida (Hautala ym. 2016).

Myös ryhmien muodostaminen suorituskyvyn lähtötason mukaan yhtenäisemmiksi kuin tässä projektissa oli mahdollista tuottaisi todennäköisesti selvemmän suorituskyvyn paranemisen. Vastaavia suosituksia ohjelmien yksilölliseksi tai ryhmäkohtaiseksi räätälöimiseksi ja suuntaamiseksi on esitetty jo pitkään (Donker 2000; Rantala \&t Virtanen 2008), mutta käytännössä tämän suuntainen kehitys näyttää olevan varsin hidasta (Hämäläinen Et Röberg 2007; Mäkinen \&t Penttilä 2007a, 2007b). Kuntoutuksen käytännön ja menetelmien kehittämisen kannalta tämän tutkimuksen tulokset näyttävät korostavan fyysisen toimintakyvyn kohentamisen ja säilyttämisen merkitystä myös iäkkäämpien sepelvaltimotautipotilaiden kohdalla. Vastaavan suuntaisia, sydänkuntoutuksen tehostamiseen tähtääviä suosituksia on esitetty tuoreessa suomalaisessa artikkelissa (Hautala ym. 2016). 
Tulosten merkitys: Kuntoutuksen käytännön kehittämisen kannalta tämän tutkimuksen tulokset korostavat fyysisen toimintakyvyn kohentamisen ja säilyttämisen merkitystä myös iäkkäämpien sepelvaltimotautipotilaiden kohdalla. Liikunnallisen kuntoutuksen tuloksellinen toteutus näyttäisi kuitenkin edellyttävän kuntoutusryhmän koon pitämistä suhteellisen pienenä, alle 10 osallistujan kokoisena. Tällöin myös ryhmien muodostaminen suorituskyvyn lähtötason mukaan yhtenäisemmiksi olisi mahdollista ja tuottaisi todennäköisesti selvemmän suorituskyvyn paranemisen. Jatkotutkimuksissa olisi tärkeää selvittää sydänkuntoutuksen mahdollisia vaikutuksia paitsi erikoissairaanhoidon myös avoterveydenhuollon palvelujen tarpeeseen ja käyttöön.

\section{Tiivistelmä}

Sydänkuntoutuksen vaikuttavuutta on perinteisesti arvioitu käyttäen osoittimina vaaratekijöiden alenemista, kuolleisuutta, työkyvyn palautumista sekä elämänlaadun kohenemista. Huomattavasti vähemmän on selvitetty sitä, onko sydänkuntoutuksella yhteyttä myöhempään terveyspalvelujen käyttöön.

Tämä tutkimus on toinen osa hanketta, jossa selvitettiin yli 60-vuotiaiden sepelvaltimotautipotilaiden kuntoutusohjelman toimivuutta ja vaikuttavuutta satunnaistetulla, kontrolloidulla tutkimusasetelmalla. Tämän tutkimuksen toisen vaiheen tavoitteena oli selvittää iäkkäille sydänpotilaille suunnatun kuntoutusohjelman mahdollinen yhteys myöhempään erikoissairaanhoidon palvelujen käyttöön sekä tutkia, mitkä perussairauteen, vaa- ratekijöihin tai toimintakykyyn liittyvät tekijät voisivat selittää palvelujen käyttöä.

Hankkeeseen osallistui kaikkiaan 312 sepelvaltimotautipotilasta, jotka oli satunnaistettu kuntoutusryhmään ja vertailuryhmään. THL:n Hilmo-tietokannasta laskettiin kahden ja puolen vuoden ajalta erikoissairaanhoidon toimenpiteiden ja käyntimäärien summa, jossa otettiin huomioon sydän- ja verisuonitautien hoidon vuoksi tapahtuneet käynnit ja toimenpiteet.

Tulokset osoittivat, että lähes puolella osallistujista (44,8 \%) ei ollut lainkaan rekisteriin merkittyjä erikoissairaanhoidon käyntejä tai toimenpiteitä 2,5 vuoden seurantajakson aikana. Palveluja käyttäneiden käyntimäärät vaihtelivat yleisimmin (41,7 \%) välillä 1-5/seurantajakso, ja vain 13,3 \%:n osalta käyntejä tai toimenpiteitä oli tätä enemmän. Kajoavien toimenpiteiden osuus kaikista käynneistä oli vain 1,6 $\%$.

Kuntoutusinterventioon osallistuneiden ja verrokkien välillä ei ollut eroa palvelujen käytössä. Voimakkaimmin käyntimääriä selittäväksi tekijäryhmäksi osoittautuivat fyysistä suoritusja toimintakykyä kuvaavat muuttujat, erityisesti rasituskokeen tulos. Kuntoutuksen menetelmien kehittämisen kannalta tämän tutkimuksen tulokset tukevat tuoreimpia suosituksia, jotka korostavat fyysisen toimintakyvyn kohentamisen ja säilyttämisen merkitystä myös iäkkäämpien sepelvaltimotautipotilaiden kohdalla.

Avainsanat: sepelvaltimotauti; sydänkuntoutus; terveyspalvelujen käyttö; ikääntyminen; fyysinen suorituskyky 


\section{Abstract}

Rehabilitation of elderly coronary heart disease patients and use of special health care services. Results of a randomized, controlled trial.

Risk factor levels, mortality, and physical as well as psycho-social functioning have traditionally been used as out-come criteria for efficacy of cardiac rehabilitation. Less is known about the possible impact of cardiac rehabilitation on use of later health care services.

This report is the second part of a project where the feasibility and efficacy of an age-tailored rehabilitation program for cardiac patients over 60 years of age was evaluated. A controlled, randomized design was used. Subjects in the intervention group participated in a weekly organized, ten-day rehabilitation program. Control group participated in same assessments (including risk factor evaluation with laboratory tests and questionnaires, and exercise test), otherwise they were treated and followed-up according to usual care.

The aim of this second part of the study was to evaluate if the applied rehabilitation program had any impact on the use of special health care services during the following two and half years. And, furthermore, to investigate which disease related, risk factors and/or indicators of functional capacity might predict use of services.

Participants were 312 coronary heart disease patients (mean age 69,5 yrs, women 46,8 \%) recruited from health centers in cities of Helsinki and Vantaa. For each patient, the number of visits or interventions related to vascular health, and recorded as a special health care service was calculated from the Hilmo-register, provided by the $\mathrm{Na}$ tional Institute for Health and Wellfare. Also, data of mortality and causes of death were received from Statistics Finland data base.

Results showed that nearly half $(44,8 \%)$ of the participants had no registered visits or interventions in special health care because of vascular health problems. The number of visits for those who had used special health care varied usually $(41,7 \%)$ between one to five, and only for $13,3 \%$ of participants the total number of visits exceeded five. The total number of invasive interventions was only 11, i.e., $1,6 \%$ of all visits.

Between the two study groups there was no difference in the number of special health care visits or interventions. The most significant predictors of high number of visits were factors related to poor physical functioning, especially a low functional capacity in the clinical exercise test. Even statistically significant raw correlations of some socio-demographic factors such as old age and living alone for men with the number of visits lost their significance when analyzed together with indicators of physical functioning.

In sum, the results of this study support the recent recommendations for cardiac rehabilitation which underline the importance of promotion and maintenance of good physical functioning also among elderly coronary patients.

Key words: coronary heart disease; cardiac rehabilitation; health services; ageing; physical fitness 


\section{Juhani Julkunen, professori (emeritus), FT, Helsingin yliopisto, Kuntoutussäätiö}

Tuula Lehikoinen, erikoissuunnittelija, FM, Kuntoutussäätiö

Mila Gustavsson-Lilius, terveyspsykologian erikoispsykologi, PsT, Kuntoutussäätiö

Hannu Vanhanen, LKT, sisätautien

erikoislääkäri, dosentti

\section{Lähteet}

Aalto A-M, Teperi J, Aro AR (1999) Rand-36 terveyteen liittyvän elämänlaadun mittarina: Mittarin luotettavuus ja suomalaiset väestöarvot. Tutkimuksia / Stakes Research reports, 101.

Ades PA (2001) Cardiac rehabilitation and secondary prevention of coronary heart disease. N Engl J Med 345, 892-902.

Braverman DL (2011) Cardiac rehabilitation. A contemporary review. American Journal of Physical Medicine \&t Rehabilitation 90, 599-611.

Case RB, Moss AJ, Case N, McDermott M, Eberly S (1992) Living alone after myocardial infarction: impact on prognosis. JAMA 267, 515-9.

Chen HM, Liu CK, Chen HW, Shia BC, Chen M, Chung CH (2015) Efficiency of rehabilitation after acute myocardial infarction. Kaohsiung J Med Sci 31, 351-357.

Davies E, Moxham T, Rees K, Singh S, Coats A, Ebrahim S, Lough F, Taylor R (2010) Exercise training for systolic heart failure: Cochrane systematic review and meta-analysis. European Journal of Heart Failure, 12, 706-715.

Donker FJS (2000) Cardiac rehabilitation: A review of current developments. Clinical Psychology Review 20, 923-943.

Hautala AJ, Alapappila A, Häkkinen H, Kettunen J, Laukkanen J, Meinilä L, Savonen K (2016) Sepelvaltimotautipotilaat liikunnalliseen kuntoutukseen. Suomen Lääkärilehti 71, 2652-2655.

Heran BB, Chen J, Ebrahim S, Moxham T, Oldbridge N, Rees K, Thompson DR, Taylor RS (2011) Exercisebased cardiac rehabilitation for coronary heart disease. The Cochrane Library, Issue 7.

Hämäläinen H, Röberg M (2007) Sydänkuntoutus osana moniulotteista palveluketjua. Suomen Lääkärilehti 62, 3771-3775.

Julkunen J, Ahlström R (2006) Hostility, anger, and sense of coherence as predictors of health-related quality of life. Results of an ASCOT substudy. J Psychosom Res 61, 33-39.

Julkunen J, Pietilä P, Gustavsson-Lilius M, Sala R,
Sauliala T, Notkola V (2012) Yli 60-vuotiaiden sepelvaltimotautia sairastavien avokuntoutuksen kehittäminen ja vaikuttavuuden arviointi (Sydän 60+). Kuntoutussäätiön Tutkimuksia. Research Reports 85/2012. Helsinki 2012.

Keeley RD, Driscoll M (2010) A moderator-mediator analysis of coronary heart disease mortality. J Psychosom Res 69, 549-554.

Käypä hoito -suositus (2011) Lihavuus (aikuiset): Suomalaisen Lääkäriseuran Duodecimin ja Suomen Lihavuustutkijat ry:n asettama työryhmä. Helsinki: Suomalainen Lääkäriseura Duodecim. (Viitattu 12.1.2012). Saatavilla Internetissä: www.kaypahoito.fi

Müller-Riemenschneider F, Meinhard C, Damm K, Vauth C, Bockelbrink A, Greiner W \&t Willich S (2010) Effectiveness of nonpharmacological secondary prevention of coronary heart disease. European Journal of Cardiovascular Prevention \& Rehabilitation, 17, 688-700.

Mäkinen A, Penttilä UR (2007a) Sepelvaltimotautipotilaiden kuntoutus julkisessa terveydenhuollossa. Selvitys kuntoutuksen määrästä, sisällöstä ja järjestämistavoista. Suomen Sydänliiton julkaisuja 2007:1.

Mäkinen A, Penttilä UR (2007b) Suomi on sepelvaltimokuntoutuksen takapajula. Suomen Lääkärilehti 62, 4656-4657.

O'Shea JC, Wicox RG, Skene AM ym. (2002) Comparison of outcomes o patients with myocardial infarction when living alone versus those not living alone. Am J Cardiol 90,1374-7.

Purmonen T, Tyrväinen V, Purmonen T, Rytkönen A, Kataja V (2016) Erikoissairaanhoidon palvelujen käyttö KeskiSuomen sairaanhoitopiirissä. Suomen Lääkärilehti 71, 417-424.

Raitasalo R (2007) Mielialakysely. Suomen oloihin Beckin lyhyen depressiokyselyn pohjalta kehitetty masennusoireilun ja itsetunnon kysely. Sosiaali- ja terveysturvan tutkimuksia 86.

Rantala M, Virtanen V (2008) Kannattaako sydänpotilaan kuntoutus? Duodecim 124, 254-60.

Renfors T (2005) Laitoskuntoutus ei vähennä palvelujen kysyntää. IMPAKTI 3/2005, 16-17.

Salminen M, Sintonen H, Vahlberg T, Isoaho R, Verronen S, Kivelä S-L (2006) Sepelvaltimotautia sairastavien iäkkäiden elämänlaatu. Yleislääkäri, 1, 24-26.

Salomaa V, Havulinna AS, Koukkunen H, Kärjä-Koskenkari P, Juolevi A, Mustonen J, Ketonen M, Lehtonen A, Immonen-Räihä P, Lehto S, Airaksinen J, Kesäniemi YA, Finami- tutkimusryhmä (2014) Sepelvaltimotautitapahtumine ilmaantuvuus on 
vähentynyt ja ennuste parantunut. FINAMI-tutkimuksen tuloksia 1993-2007. Suomen Lääkärilehti 69, 31-36.

Schmaltz HN, Southern D, Ghali WA, Jelinski SE, Parsons GA, King KM, Maxwell CJ (2007) Living alone, patient sex and mortality after acute myocardial infarction. Journal of General Internal Medicine 22, 572-78.

Suomen virallinen tilasto (2014) (SVT) Kuolemansyyt [verkkojulkaisu].

ISSN=1799-5051. Liitetaulukko 1a. Kuolleet peruskuolemansyyn ja iän mukaan 2014, molemmat sukupuolet. Helsinki: Tilastokeskus [viitattu: 24.10.2016].

Taylor RS, Brown A, Ebrahim S, Jolliffe J, Noorani H, Rees K, ym. (2004) Exercise-based rehabilitation for patients with coronary heart disease: systematic review and meta-analysis of randomized controlled trials. Am J Med, 116, 682-92.

Witt BJ, Jacobsen SJ, Weston SA, Killian JM, Meverden RA, Allison TG, Reeder GS (2004) Cardiac rehabilitation after myocardial infarction in the community. J Am College of Cardiology 44, 988-96. 